\title{
KORELASI PERSEPSI KUALITAS ONLINE DENGAN KEPUASAN LAYANAN SISTEM INFORMASI AKADEMIK MAHASISWA DI STMIK SINAR NUSANTARA SURAKARTA
}

\author{
Wahyu Catur Hastuti ${ }^{1)}$, Tri Irawati ${ }^{2)}$, Wawan Laksito ${ }^{3)}$ \\ ${ }^{1)}$ Program Studi Sistem Informasi, STMIK Sinar Nusantara Surakarta \\ ${ }^{2)}$ Program Studi Komputerisasi Akuntansi, STMIK Sinar Nusantara Surakarta \\ ${ }^{3)}$ Program Studi Teknik Informatika, STMIK Sinar Nusantara Surakarta \\ ${ }^{1)}$ w4hyucatur@gmail.com, ${ }^{2)}$ irawati3@yahoo.co.id, ${ }^{3)}$ wlaksito@yahoo.com
}

\begin{abstract}
This research to determine the correlation between the perception of the quality of service satisfaction online with students' academic information system STMIK Sinar Nusantara use today (www.akademik.sinus.ac.id). The population in this study were all students STMIK Sinar Nusantara Surakarta. Total sample of 55 students using a questionnaire to determine the response of students to each variable. Based on the results if the data do content (X1), accurate (X2), format (X3), easy of use (X4), and timeliness (X5) simultaneously or jointly influencing variables Student Satisfaction $(Y)$ and the result is erarti $10.3 \%$ of independent variables in this study could affect the dependent variable, while the rest $(100 \%-10.3 \%=$ $89.7 \%)$ is explained by other causes beyond the model that are not investigated in this study.
\end{abstract}

Keywords: correlation, online quality, service satisfaction student information system

\section{PENDAHULUAN}

Semakin meningkat kebutuhan masyarakat terhadap pendidikan formal, khususnya pendidikan tinggi, menjadikan perguruan tinggi sebagai yang bermutu. STMIK Sinar Nusantara dituntut harus dapat mengelola institusinya secara professional, salah satunya adalah dengan merubah atau terjadi perubahan layanan sistem informasi akademik yang awalnya di www.siakad.sinus.ac.id disempurnakan menjadi www.akademik.sinus.ac.id yang dapat dimanfaatkan mahasiswa untuk mengevaluasi ataupun merencanakan kegiatan perkuliahannya dengan mudah dan cepat.

Sebagai salah satu unsur yang dapat digunakan untuk menganalisis tingkat kepuasan pengguna Sistem Informasi yang ada di STMIIK Sinar Nusantara adalah tingkat kepuasan dan ketidakpuasan mahasiswa yang sangat dipengaruhi oleh harapan dan kinerja sistem. Adapun kualitas sistem informasi STMIK Sinar Nusantara yang akan diteliti adalah website www.akademik.sinus.ac.id.

Berdasarkan uraian latar belakang diatas, maka dalam penyusunan skripsi ini penulis menekankan pada permasalahan adalah " Mengetahui Tingkat Korelasi Antara Persepsi Kualitas Online Dengan Kepuasan Layanan Sistem Informasi Akademik Mahasiswa Di STMIK Sinar Nusantara Surakarta dengan membandingkan nilai variabel yang ada di www.akademik.sinus.ac.id . Karakteristik variabel tersebut terdiri dari unsur content, accuracy, format, easy of use, dan timeliness." 


\section{TINJAUAN PUSTAKA}

\subsection{Persepsi}

Persepsi dapat mempengaruhi tingkah laku seseorang terhadap sutu objek dan situasi lingkungannya. Dengan kata lain, tingkah laku seseorang terhadap suatu objek dipengaruhi oleh lingkungannya.

Persepsi menurut Walgito merupakan suatu proses yang didahului oleh penginderaan yaitu proses diterimanya stimulus oleh individu melaluui alat indera namun proses itu tidak berhenti begitu saja melainkan stimulus tersebut diteruskan dan proses selanjutnya merupakan proses persepsi (Walgito B. , 2002)

\subsection{Kualitas}

Pengertian atau makna atas konsep kualitas telah diberikan oleh banyak pakar dengan berbagai sudut pandang yang berbeda, sehingga menghasilkan definisi-definisi yang berbeda pula. Goesth dan Davis yang dikutip Tjiptono, mengemukakan bahwa kualitas diartikan "sebagai suatu kondisi dinamis dimana yang berhubungan dengan produk, jasa, manusia, proses dan lingkungan yang memenuhi atau melebihi harapan". (Fandy, Candra, \& Georgious, 2007)

Pengertian yang lebih rinci tentang kualitas diberikan oleh Tjiptono, setelah melakukan evaluasi dari definisi kualitas beberapa pakar, kemudian Tjiptono menarik 7 (tujuh) definisi yang sering dikemukakan terhadap konsep kualitas, definisi-definisi kualitas menurut Tjiptono tersebut, adalah sebagai berikut:

1) Kesesuaian dengan persyaratan atau tuntutan;

2) Kecocokan untuk pemakaian;

3) Perbaikan atau penyempurnaan berkelanjutan:

4) Bebas dari kerusakan atau cacat;

5) Pemenuhuan kebutuhan pelanggan semenjak awal dan setiap saat;

6) Melakukan segala sesuatu secara benar semenjak awal; dan

7) Sesuatu yang bisa membahagiakan pelanggan.

Kualitas sistem informasi merupakan karakteristik dari informasi yang melekat mengenai sistem itu sendiri. Davis serta Chin and Todd mendefinisikan kualitas sistem sebagai perceived ease of use yang merupakan seberapa besar teknologi komputer dirasakan relatif mudah untuk dipahami dan digunakan. (Tjiotono, 2008)

\subsection{Kepuasan}

Kepuasan pengguna sistem informasi adalah cara pengguna memandang dan menggunakan sistem informasi secara nyata, bukan pada kualitas sistem secara teknik. (J D McKeen, 2003)

\section{METODE PENELITIAN}

\subsection{Populasi dan Sampel}

Populasi dalam penelitian ini adalah seluruh mahasiswa STMIK Sinar Nusantara dari 3 (tiga) program studi Diploma III, yaitu Manajemen Informatika, Komputerisasi Akuntansi, dan Teknik Informatika, serta 2 (dua) program studi Strata 1, yakni Sistem Informasi dan Teknik Informatika. 
Pengguna yang dijadikan sampel adalah mahasiswa STMIK Sinar Nusantara Surakarta. Dikarenakan keterbatasan waktu dan aktivitas mahasiswa belum sepenuhnya ada di kampus maka jumlah sampel yang ada sebanyak 55 mahasiswa.

\subsection{Pengukuran Variabel Dependen}

Variabel dependen merupakan variabel yang menjadi pusat perhatian peneliti. Variabel dependen yang digunakan dalam penelitian ini adalah kepuasan pelanggan / mahasiswa (Y). Instrumen yang digunakan dalam penelitian ini adalah kuesioner. Berdasarkan pertanyaan tersebut akan menggunakan skala Likert untuk pengukuran hasil $1-4$ yang didistribusikan.

\subsection{Pengukuran Variabel Independen}

Variabel independen yang dilambangkan dengan (X) adalah variabel yang diharapkan sesuai dengan indikator kualitas layanan sistem informasi yang digunakan (www.sinus.ac.id). Variabel independen pada penelitian ini diantaranya:

1. Content / konten $\left(\mathrm{X}_{1}\right)$

2. Accuracy / Akurat $\left(\mathrm{X}_{2}\right)$

3. Format $\left(\mathrm{X}_{3}\right)$

4. Easy of use / mudah digunakan $\left(\mathrm{X}_{4}\right)$

5. Timeliness / tepat waktu $\left(\mathrm{X}_{5}\right)$

\subsection{Tahapan Uji Analisa Data}

1. Pengumpulan data yang diteliti berupa nilai skala $1-4$ meliputi kuesioner variabel konten, akurat, format, easy of use (mudah digunakan), dan timeliness (tepat waktu).

2. Data diolah menggunakan SPSS IBM SPSS Statistics 19 untuk mengetahui nilai yang diperoleh setelah melalui proses pengolahan data.

3. Menentukan hipotesis yang digunakan untuk mengetahui apakah ada hubungan signifikansi atau tidak antara variabel bebas dengan variabel terikat.

\section{HASIL DAN PEMBAHASAN}

\subsection{Deskripsi Sampel}

Metode survei merupakan penelitian yang biasa dilakukan dengan subjek yang banyak, dimaksudkan untuk mengumpulkan pendapat atau informasi mengenai status gejala pada waktu penelitian berlangsung. Kuesioner adalah sejumlah pertanyaan tertulis yang digunakan untuk memperoleh informasi dari responden dalam arti laporan tentang pribadinya, atau hal-hal yang dia ketahui. Dikarenakan keterbatasan waktu dan aktivitas mahasiswa belum sepenuhnya ada di kampus maka jumlah sampel yang ada sebanyak 55 mahasiswa. (Imam, 2011).

\subsection{Uji Validitas}

Validitas dilakukan untuk mengukur sah/validnya suatu kuesioner. Suatu Uji kuesioner dinyatakan valid jika pertanyaan pada kuesioner mampu untuk 
mengungkapkan sesuatu yang akan diukur oleh kuesioner tersebut. Uji validitas ini membandingkan nilai masing-masing item pertanyaan dengan nilai total.

Dari hasil pengujian diketahui bahwa pada masing-masing pertanyaan mempunyai $r_{\text {hitung }}$ yang lebih besar dari $r_{\text {tabel }}(0,2609)$, maka dapat disimpulkan bahwa seluruh pertanyaan layak untuk dianalisis.

\subsection{Uji Reliabilitas}

Uji Reliabilitas merupakan uji kehandalan yang bertujuan untuk mengetahui sebarapa jauh alat ukur tersebut dapat dipercaya. Kehandalan berkaitan dengan seberapa jauh suatu alat ukur konsisten apabila pengukuran dilakukan secara berulang dengan sampel yang berbeda-beda.

Dari hasil uji reliabilitas dapat diketahui bahwa semua variabel dalam penelitian ini dinyatakan Reliabel karena masing-masing nilai Cronbach's alpha pada variabel tersebut $>0,06$. Dengan melihat hasil analisis validitas dan reliabiltas di atas, dapat ditarik kesimpulan bahwa kuesioner dapat dipakai pada proses penelitian selanjutnya yaitu uji hipotesis.

\subsection{Uji Normalitas}

Uji normalitas bertujuan untuk menguji apakah dalam model regresi, variabel terikat, variabel bebas atau keduanya mempunyai distribusi normal atau tidak.

Pengujian ini dilakukan untuk menguji apakah variabel pengganggu atau residual dalam model regresi memiliki distribusi normal. Hasil uji normalitas dengan menggunakan uji Kolmogorov-Smirnov dapat dilihat seperti pada Tabel 1 .

Tabel 1. Hasil Uji Normalitas

\begin{tabular}{|c|c|c|c|}
\hline Variabel & $\begin{array}{c}\text { Kolmolgorov- } \\
\text { smirnov } Z\end{array}$ & -value & Keterangan \\
\hline Unstandardized Residual & 0,739 & 0,645 & Data terdistribusi normal \\
\hline
\end{tabular}

Uji normalitas dengan menggunakan uji Kolmogorov-Smirnov Test menunjukkan nilai Kolmogorov-Smirnov sebesar 0,739 dan nilai signifikasi sebesar 0,645 jadi data terdistribusi bersifat normal karena nilai signifikasi lebih besar dari 0,05 .

\subsection{Uji Heterokedastisitas}

Pengujian ini dilakukan untuk menguji apakah dalam regresi terjadi ketidaksamaan variance dari residual satu pengamatan ke pengamatan lain. Deteksi ada tidaknya heteroskedastisitas dapat dilakukan dengan menggunakan uji Glejser. Hasil uji heteroskedastisitas dengan menggunakan uji glejser dapat dilihat dalam Tabel 2.

Tabel 2. Hasil Uji Heteroskedastisitas

\begin{tabular}{|l|r|r|}
\hline Model & \multicolumn{1}{|l|}{ T } & \multicolumn{1}{|l|}{ Sig. } \\
\hline 1 (Constant) & $-2,450$ &, 018 \\
\hline$X_{1}$ &, 481 &, 633 \\
\hline$X_{2}$ & 2,256 &, 029 \\
\hline$X_{3}$ & $-1,325$ &, 191 \\
\hline$X_{4}$ & 2,808 &, 007 \\
\hline$X_{5}$ &,- 265 &, 792 \\
\hline
\end{tabular}


Hasil uji heteroskedastisitas dengan menggunakan uji glejser menunjukkan bahwa koefisien parameter untuk variabel independen tidak ada yang signifikan pada 0,01 . Jadi dapat disimpulkan bahwa terjadi heteroskedastisitas dalam 1 (satu) model regresi yang digunakan dalam penelitian ini tapi masih tergolong data yang normal.

\subsection{Uji Multikolinearitas}

Uji multikolinieritas dilakukan untuk menguji apakah model dalam regresi ditemukan adanya korelasi antar variabel independen. Hasil multikolinieritas dengan menggunakan tolerance dan nilai VIF dapat dilihat dalam Tabel 3.

Tabel 3. Hasil Uji Multikolinearitas

\begin{tabular}{|l|l|l|}
\hline Model & Tolerance & VIF \\
\hline $1($ Constant $)$ &, 423 & 2,363 \\
\hline $\mathrm{X}_{1}$ &, 487 & 2,054 \\
\hline $\mathrm{X}_{2}$ &, 508 & 1,970 \\
\hline $\mathrm{X}_{3}$ &, 724 & 1,382 \\
\hline $\mathrm{X}_{4}$ &, 677 & 1,478 \\
\hline $\mathrm{X}_{5}$ &, 423 & 2,363 \\
\hline
\end{tabular}

Hasil uji multikolinieritas pada tabel 4.6 menunjukkan bahwa semua variabel dalam penelitian ini memiliki nilai tolerance $>0,01$ dan semua variabel memiliki nilai $V I F<10$, jadi dapat disimpulkan bahwa tidak terjadi multikolinieritas antar variabel independen dalam model regresi yang digunakan dalam penelitian ini.

\subsection{Uji T}

Pengujian ini digunakan untuk mengetahui apakah masing-masing variabel independen dapat mempengaruhi terhadap variabel dependen. Cara menentukan df (derajat kebebasan) tersebut adalah dengan menggunakan rumus sebagai berikut : $\mathrm{df}=\mathrm{n}-1$

Keterangan : Dimana $\mathrm{n}$ adalah jumlah observasi atau sampel pembentuk regresi. Pada pembahasan ini diketahui persamaan regresi dengan lima variabel bebas dan satu variabel terikat. Jumlah sampel pembentuk regresi tersebut sebanyak 60. Maka df =n-1 = 55-1 = 54. Pengujian menggunakan tingkat signifikansi 0,05 dan 2 sisi dengan hipotesis sebagai berikut :

a. $\mathrm{H}_{0}$ diterima berarti variabel independen $\left(\mathrm{X}_{1}, \mathrm{X}_{2}, \mathrm{X}_{3}, \mathrm{X}_{4}\right.$ dan $\left.\mathrm{X}_{5}\right)$ dalam layanan sistem informasi akademik online tidak berpengaruh atau berkorelasi terhadap kepuasan mahasiswa.

b. $\mathrm{H}_{0}$ ditolak berarti variabel independen $\left(\mathrm{X}_{1}, \mathrm{X}_{2}, \mathrm{X}_{3}, \mathrm{X}_{4}\right.$ dan $\left.\mathrm{X}_{5}\right)$ dalam layanan sistem infomasi akademik online berpengaruh atau berkorelasi terhadap kepuasan mahasiswa.

Adapun hasil pengujian secara simultan seperti pada Tabel 4. 
Tabel 4. Hasil Uji Analisis Nilai t

\begin{tabular}{|l|l|l|l|l|l|}
\hline & \multicolumn{2}{|l|}{} & \multicolumn{2}{l|}{$\begin{array}{l}\text { Unstandardized } \\
\text { Coefficients }\end{array}$} & \multicolumn{2}{l|}{$\begin{array}{l}\text { Standardized } \\
\text { Coefficients }\end{array}$} & & \\
\cline { 2 - 4 } Model & B & Std. Error & Beta & $\mathrm{t}$ & Sig. \\
\hline 1 (Constant) & $-4,272$ & 1,744 & & $-2,450$ &, 018 \\
X1 &, 139 &, 289 &, 086 &, 481 &, 633 \\
X2 &, 698 &, 309 &, 378 & 2,256 &, 029 \\
X3 &,- 292 &, 220 &,- 217 & $-1,325$ &, 191 \\
X4 &, 666 &, 237 &, 385 & 2,808 &, 007 \\
X5 &,- 060 &, 227 &,- 038 &,- 265 &, 792 \\
\hline
\end{tabular}

a. Dependent Variable: ABS_RES

\subsection{Uji Determinasi}

Koefisien determinasi $\left(\mathrm{R}^{2}\right)$ mengukur seberapa jauh kemampuan model yang dibentuk dalam menerangkan variasi variabel independen. Adapun besarnya nilai koefisien determinasi ditunjukkan pada Tabel 5.

Tabel 5. Hasil Uji Koefisien Determinasi

\begin{tabular}{|l|l|l|l|l|}
\hline Model & $\mathrm{R}$ & R Square & $\begin{array}{l}\text { Adjusted R } \\
\text { Square }\end{array}$ & $\begin{array}{l}\text { Std. Error of } \\
\text { the Estimate }\end{array}$ \\
\hline 1 &, $321^{\mathrm{a}}$ &, 103 &, 012 & 3,11871 \\
\hline
\end{tabular}

Hasil analisa regresi berganda menunjukkan nilai adjusted $\mathrm{R}^{2}$ sebesar 0,103 atau sebesar $10,3 \%$. Hasil ini menunjukkan bahwa $10,3 \%$ perubahan pengungkapan kepuasan mahasiswa terhadap kualitas sistem informasi STMIK Sinar Nusantara dipengarui oleh variabel content (konten), accuracy (akurat), format, easy of use (mudah digunakan) dan timeliness (tepat waktu) sedangkan sisanya yaitu $89,70 \%$ dipengaruhi oleh faktor lain di luar model penelitian.

\subsection{Uji F}

Uji $F$ digunakan untuk membuktikan kebenaran yaitu untuk menguji keberartian koefisien regresi secara keseluruhan melalui uji $F$ dengan membandingkan $\mathrm{F}$ hitung (observasi) dengan $\mathrm{F}$ tabel pada $\alpha=0,05$. Apabila hasil pengujian menunjukkan:

a. $\mathrm{F}_{\text {hitung }}>\mathrm{F}_{\text {tabel }}$, maka $\mathrm{H}_{1}$ ditolak

Artinya $\mathrm{H}_{1}$ tidak ada korelasi antara kualitas dengan tingkat kepuasan, variasi dari model regresi berhasil menerangkan variabel bebas secara keseluruhan, sejauhmana pengaruhnya terhadap variabel terikat.

b. $\mathrm{F}_{\text {hitung }}<\mathrm{F}_{\text {tabel }}$, maka $\mathrm{H}_{1}$ diterima

Artinya $\mathrm{H}_{1}$ ada korelasi antara kualitas dengan tingkat kepuasan, variasi dari model regresi tidak berhasil menerangkan variabel bebas secara keseluruhan, sejauh mana pengaruhnya terhadap variabel terikat.

Adapun hasil pengujian secara simultan seperti pada Tabel 6 : 
Tabel 6. Hasil Uji Analisis Nilai F

\begin{tabular}{|l|l|l|l|l|l|}
\hline Model & Sum of Squares & df & $\begin{array}{l}\text { Mean } \\
\text { Square }\end{array}$ & F & Sig. \\
\hline Regression & 63,344 & 5 & 12,669 & 4,866 &, $001^{\text {a }}$ \\
Residual & 127,575 & 49 & 2,604 & & \\
Total & 190,919 & 54 & & & \\
\hline
\end{tabular}

Nilai $\mathrm{F}$ regresi digunakan untuk mengetahui pengaruh secara simultan variabel independen terhadap variabel dependen. Pada tabel 4.9 nilai $F$ menunjukkan nilai 4,866 dengan signifikan 0,001. Nilai $F$ menunjukkan hasil yang signifikan karena lebih besar dari 0,05. Sehingga secara simultan dapat disimpulkan bahwa variabel content (konten), accuracy (akurat), format, easy of use (mudah digunakan) dan timeliness (tepat waktu) mempengaruhi tingkat kepuasan mahasiswa terhadap kualitas sistem informasi akademik online STMIK Sinar Nusantara.

\section{KESIMPULAN DAN SARAN}

\subsection{Kesimpulan}

Berdasarkan hasil analisisi dan pengujian yang dilakukan ini disimpulkan bahwa jumlah sampel yaitu 55 mahasiswa melakukan pengungkapan yang terdiri dari Content (Konten), Accuracy (Akurat), Format, Easy Of Use (Mudah digunakan), dan Timeliness (Tepat Waktu) terhadap kepuasan pelayanan dari sistem akademik online (www.akademik.sinus.ac.id). Hasil analisa penelitian ini bahwa $10,3 \%$ perubahan pengungkapan kepuasan mahasiswa terhadap kualitas sistem informasi STMIK Sinar Nusantara (www.akademik.sinus.ac.id) dipengarui oleh variabel content (konten), accuracy (akurat), format, easy of use (mudah digunakan) dan timeliness (tepat waktu) sedangkan sisanya yaitu 89,70\% dipengaruhi oleh faktor lain di luar model penelitian.

\subsection{Saran}

Penelitian tentang korelasi antara persepsi kualitas online dengan kepuasan layanan sistem informasi akademik mahasiswa STMIK Sinar Nusantara Surakarta (www.akademik.sinus.ac.id) memiliki tingkat kepuasan dari variabelvariabel yang mempengaruhinya. Beberapa saran untuk penelitian selanjutnya antara lain :

a. Penelitian selanjutnya disarankan untuk Penelitian selanjutnya disarankan untuk menyempurnakan sistem akademik onlinenya sehingga kepuasan mahasiswa bisa lebih maksimal.

b. Penelitian selanjutnya dapat ditambahkan variabel kepuasan yang lain karena pengungkapan tingkat kepuasan mahasiswa masih bersifat sukarela.

c. Penelitian berikutnya disarankan menggunakan metode proprosional stratifikasi sampel, yaitu pengambilan sampel berdasarkan perbandingan prosentase dari jumlah mahasiswa yang aktif dengan total mahasiswa yang ada dengan mencakup semua jurusan, angkatan dan kelas perkuliahan. 


\section{DAFTAR PUSTAKA}

Arikunto, S. (2010). Prosedur Penelitian Suatu Pendekatan Praktik. Jakarta: Rineka Cipta.

Fandy Tjiptono; Chandra, Gregorius. (2007). Service, Quality, Satisfication Edisi Ke2. Yogyakarta: Andi.

Ghozali, I. (2011). Analisa Multivariate Dengan Pogram IBM SPSS 19. Semarang: Badan Penerbit Universitas Diponegoro.

Goetsch, David L. dan Stanley B. DAvis. (2002). Total Quality Management. In D. O. Molan, Total Kualitas Manajemen. Jakarta: Prenhallindo.

Guimaraes, T. D. S. S dan J. D. McKeen. (2003). Empirically Testing Some Main User-Related Factor for Systems Development Quality. Quality Management Journal Vol. 10 , No. 4:39-54.

Tjiptono, F. (2008). Service Management Mewujudkan Layanan Prima, Edisi Ke-2. Yogyakarta: CV. Andi Offset.

Wahid, F. (2004). Peluang Dan Tantangan Pemanfaatan Teknologi Informasi Di

Walgito, B. (2002). Pengantar Psikologi Umum Ed. 3 Cet 1. Yogyakarta: Andi Offset. 